
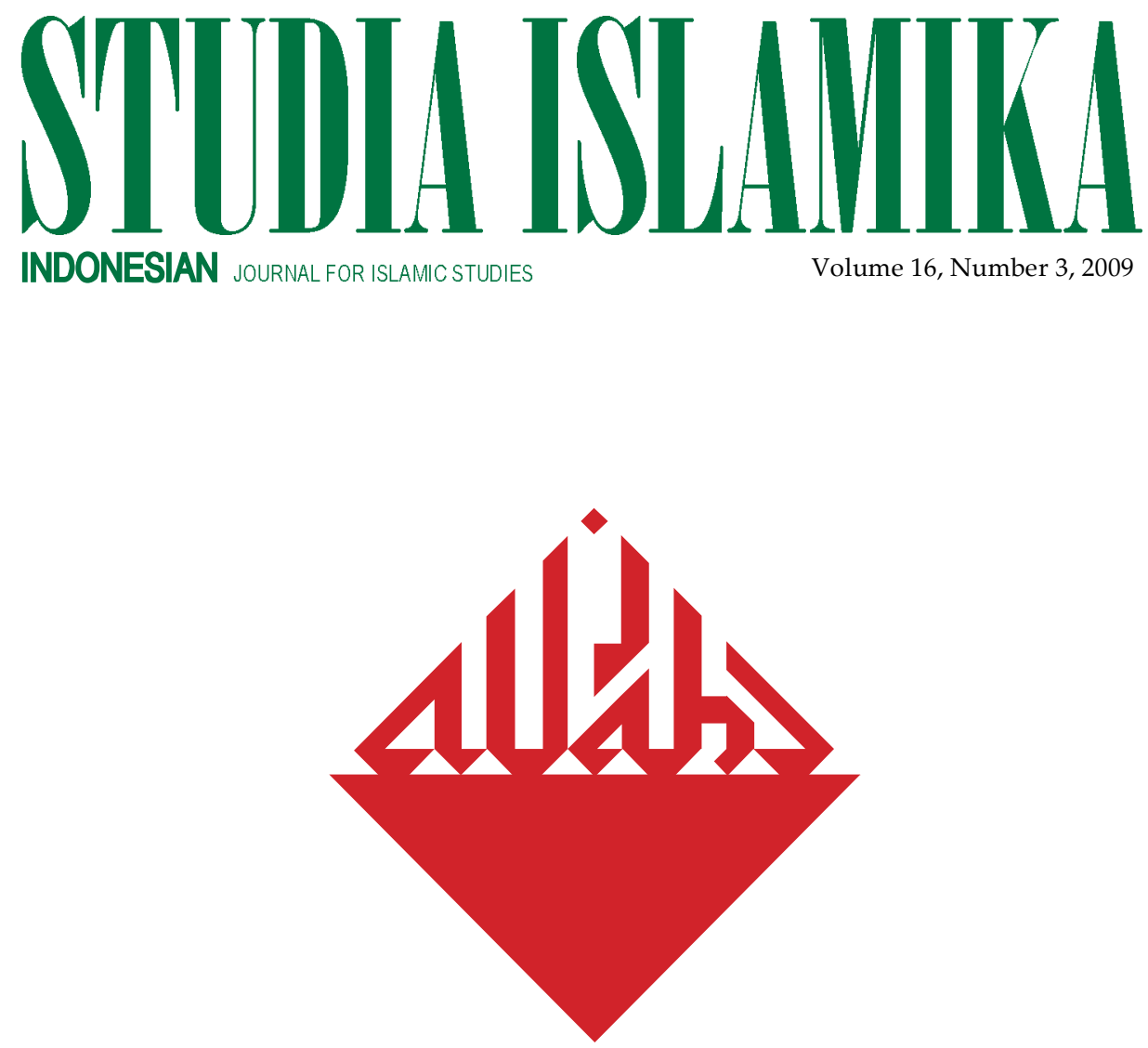

The Payung and the Rising Sun:

A Study of Javanese Pangreh Praja

DURING THE JAPANESE OCCUPATION I 942-I 945

Bahtiar Effendy

DisRupting Spatiality and Temporality:

Authority and Statecraft in HiKaYAT MARESKALEK

Ismail F. Alatas

Islamist Civil Society Activism in Malaysia under Abdullah Badawi: The Angkatan Belia Islam Malaysia (ABIM) and the Darul Arqam Ahmad Fauzi Abdul Hamid 


\section{STIDIIA ISLAMIIKK}

Indonesian Joumal for Islamic Studies

Vol. 16, no. 3, 2009

\section{EDITORIAL BOARD:}

M. Quraish Shihab (UIN Jakarta)

Taufik Abdullah (LIPI Jakarta)

Nur A. Fadhil Lubis (IAIN Sumatra Utara)

M.C. Ricklefs (National University of Singapore)

Martin van Bruinessen (Utrecht University)

John R. Bowen (Washington University, St. Louis)

M. Atho Mudzhar (UIN Jakarta)

M. Kamal Hasan (International Islamic University, Kuala Lumpur)

M. Bary Hooker (Australian National University, Australia)

Virginia Matheson Hooker (Australian National University, Australia)

\section{EDITOR-IN-CHIEF}

Azyumardi Azra

\section{EDITORS}

Jajat Burhanudin

Saiful Mujani

Jamhari

Fiad Jabali

Oman Fathurahman

\section{ASSISTANT TO THE EDITORS}

Setyadi Sulaiman

Testriono

\section{ENGLISH LANGUAGE ADVISOR}

Dick van der Meij

\section{ARABIC LANGUAGE ADVISOR \\ Nursamad}

\section{COVER DESIGNER}

\section{S. Prinka}

STUDIA ISLAMIKA (ISSN 0215-0492) is a journal published by the Center for the Study of Islam and Society (PPIM) UIN Syarif Hidayatullah, Jakarta (STT DEPPEN No. 129/SKIDITJENIPPG/ STT/1976). It specializes in Indonesian Islamic studies in particular, and South-east Asian Islamic Studies in general, and is intended to communicate original researches and current issues on the subject. This journal warmly welcomes contributions from scholars of related disciplines.

All articles published do not necessarily represent the views of the journal, or other institutions to which it is affiliated. They are solely the views of the authors. The articles contained in this journal have been refereed by the Board of Editors.

STUDIA ISLAMIKA has been accredited by The Ministry of National Education, Republic of Indonesia as an academic journal (SK Dirjen Dikti No. 83/Dikti/Kep/2009). 


\title{
Disrupting Spatiality and Temporality: Authority and Statecraft in Hikayat Mareskalek
}

\begin{abstract}
Abstrak: Penulisan sejarah tidak jarang melewatkan hal-hal detail, termasuk berbagai sensibilitas dan sentimen yang dalam beberapa hal sangat menentukan corak dan arah dari peristiwa sejarah. Hal-halyang terabaikan itu kerap terungkap dalam karya fiksi dan sastra. Hikayat Mareskalek karya Syekh Abdullah bin Muhammad al-Misri adalah salah satunya. Artikel ini mengkaji bagaimana Hikayat itu menampilkan satu wacana yang membawa kita menilik kembali sejumlah asumsi dalam karya-karya sejarah kontemporer tentang Nusantara. Asumsi-asumsi tersebut terutama terkait dengan dua hal. Pertama, geografi budaya yang terbagi atas apa yang dianggap sebagai "Melayu" dan "Jawa". Kedua, konstruk temporal di mana modernitas terjadi sebagai hasil dari perjumpanaan masyarakat dengan kolonialisme.
\end{abstract}

Abdullah bin Muhammad al-Misri, penulis Hikayat Mareskalek, hidup antara akbir abad ke-18 dan awal abad ke-19, pada masa peralihan dari Inggris ke Belanda. Hikayat Mareskalek sendiri ditulis al-Misri lima tahun setelab kepergian Daendels, selama ia tinggal di Besuki, Jawa Timur. Hikayat Mareskalek memuat visi politik al-Misri yang bukan berbasis pada konsep-konsep Eropa modern sebagai hasil dari perjumpaan dengan kolonialisme, melainkan sebagai kontinuitas dari teori-teori politik Sunni abad pertengahan. Bagi al-Misri, penanda dimulainya abad modern di Nusantara (termasuk Malaysia) bukanlah kolonialisme Eropa, melainkan pertentangan berkepanjangan antara dunia agraris dan sistem perdagangan di Nusantara. Pertentangan dua kutub itulah yang menurut Denys Lombard menjadi kata kunci untuk memahami sejarah Nusantara.

Al-Misri memang menjadikan konsep individu sebagai basis dari visi politiknya. Namun, konsep individu itu ia adopsi dari teori-teori politik Sunni seperti dikemukakan oleh al-Mawardī, al-Nizäm, dan al-Ghazälì. Itu terlihat bagaimana al-Misri menggambarkan Daendels, Gubernur Jenderal Belanda 
yang sangat terkenal lewat proyek Jalan Raya Pos yang menghubungkan ujung barat dan ujung timur pulau Jawa, dari Anyer sampai Panarukan. Dalam hal ini, dia digambarkan sebagai salah satu tokoh sentral dalam karya sastra ini bukan sebagai representasi pemikiran politik Eropa modern, melainkan sebagai pembawa pesan dari pemikiran Sunni abad pertengahan.

Basis individu pula yang menjadi dasar bagi al-Misri dalam menjelaskan konsep negara dan otoritas. Al-Misri mendefinisikan individu sebagai makhluk ekonomi (economic being) yang membutubkan perdagangan guna memenuhi kebutuhan hidupnya. Dan karena perdagangan sangat penting bagi mata pencaharian manusia, maka raison d'etre eksistensi negara tidak lain adalah menggaransi keberlangsungan praktik perdagangan tersebut. Sehingga, bagi al-Misri, pemimpin yang berhasil adalah mereka yang bisa menarik dan mewujudkan iklim kondusif bagi perdagangan. Individu juga menjadi basis bagi konsep otoritas dalam Hikayat Mareskalek. Menurut al-Misri, otoritas harus diberikan kepada orang yang memang benar-benar layak mendapatkannya. Dan kelayakan itu sama sekali tidak ditentukan berdasarkan faktor genealogis, melainkan kapasitas personal. Setiap individu, menurut al Misri, memiliki kesempatan yang sama untuk mendapatkan otoritas, untuk menjadi pemimpin.

Meski memiliki kesan baik kepada Daendels dan VOC, dalam Hikayat Mareskalek al-Misri juga memberikan kritik terhadap arogansi Daendels dan ketidakmampuan VOC menangani masalah perpajakan. Kritik juga ia arabkan kepada Kerajaan Mataram yang tidak berhasil menjalankan pemerintahan karena lebih mengedepankan konsep tradisional kosmologi Jawa, di mana takdir paling menentukan posisi seseorang dalam lingkungan sosial. Kritik lain diajukan al Misri kepada pemerintahan Kerajaan Mataram yang terlalu memposisikan diri sebagai pelindung peraturan dengan intervensi yang sangat tinggi, sebuah konsep yang sama sekali tidak cocok untuk memajukan kerajaan.

Dengan menganalisis Hikayat Mareskalek, artikel ini menentang kedua asumsi mengenai geografi budaya yang terbagi atas "Melayu" dan "Jawa" dan batas temporal di mana keterpisahan dengan masa lalu terjadi sebagai hasil dari perjumpaan dengan kolonial. "Melayu" dan "Jawa" adalah kompleks kultural yang saling terkait dan cair. Sementara basis politik modern di Nusantara bukanlah konsep individu Eropa, melainkan teori-teori politik dalam ajaran Sunni abad pertengahan. Dengan demikian, artikel ini menunjukkan babwa Hikayat Mareskalek menjadi jalan untuk merevisi asumsi-asumsi yang berkembang dalam kajian-kajian Asia Tenggara selama ini. 
Disrupting Spatiality and Temporality:

Authority and Statecraft in Hikayat Mareskalek

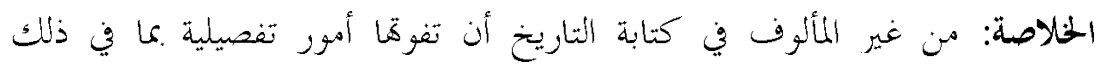

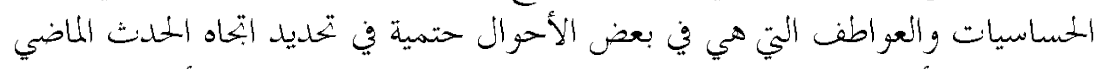

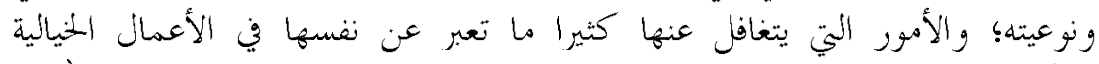

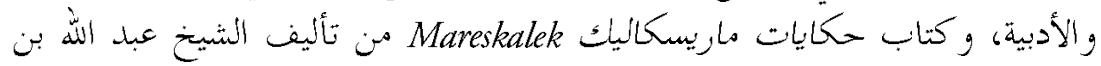

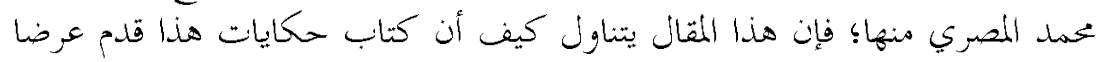

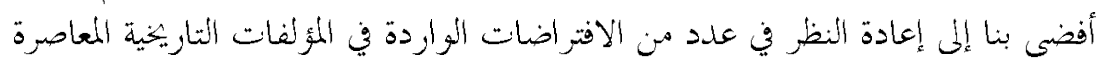

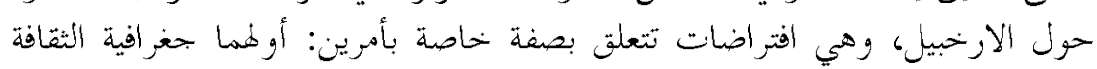

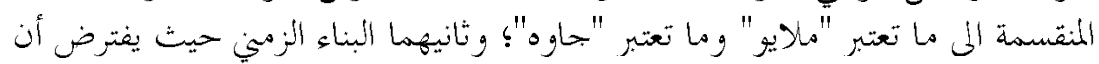

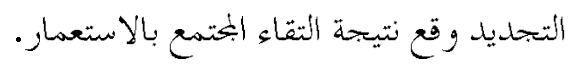

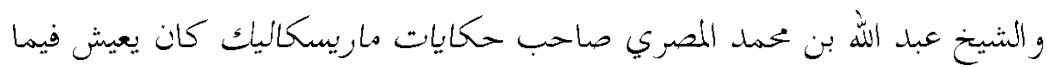

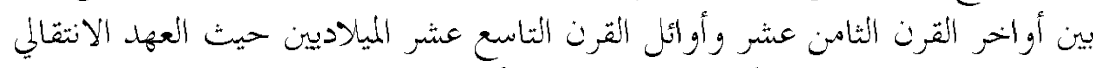

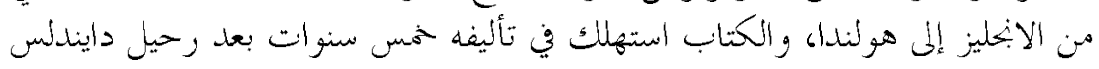

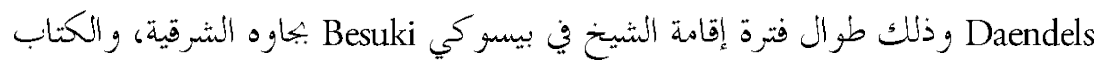

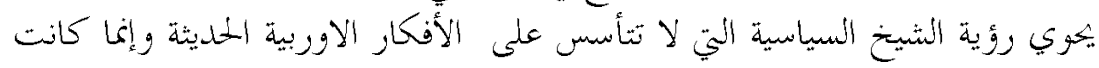

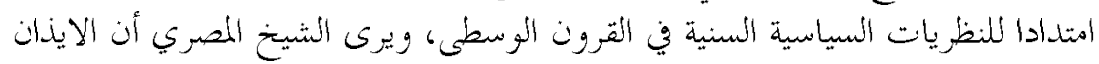

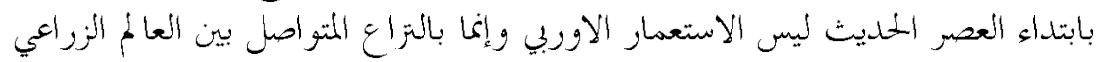

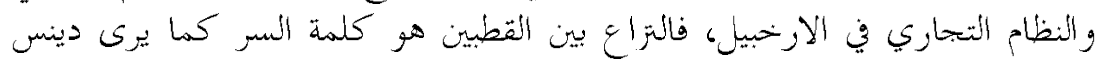

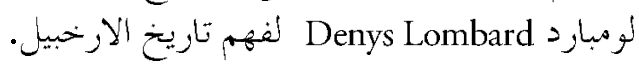

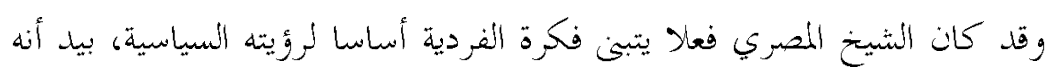

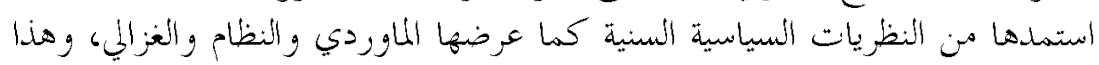
ظاهر في تصويره عن شخصية دايندلس الحاكم العام الهولندي النذي أطبقت شئت شهرته 


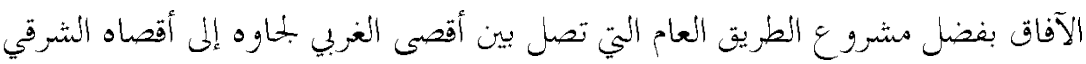

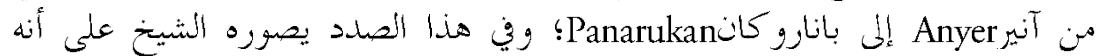

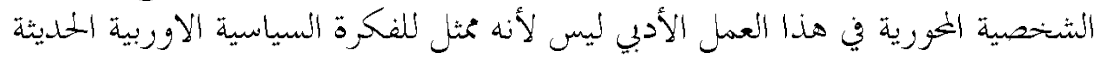

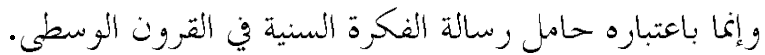

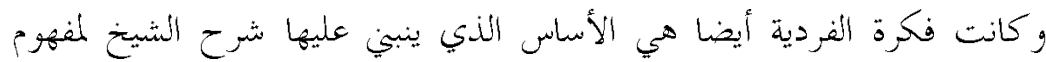

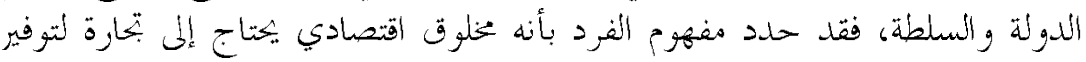

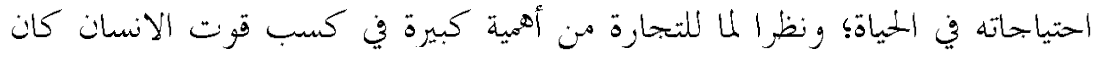

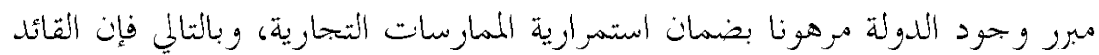

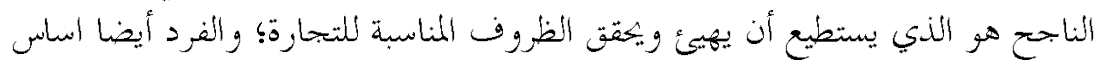

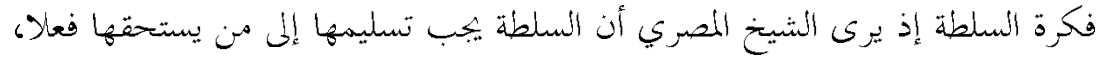

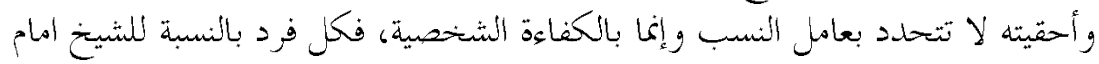

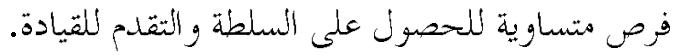

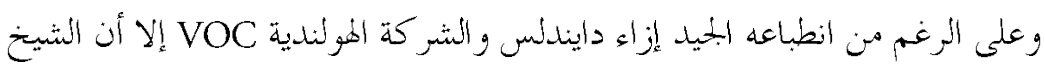

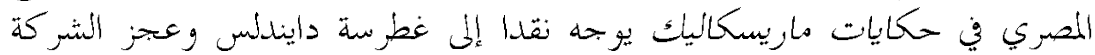

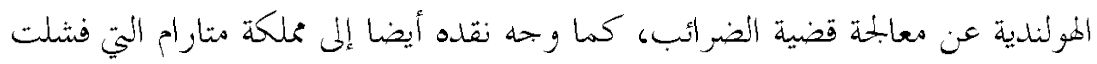

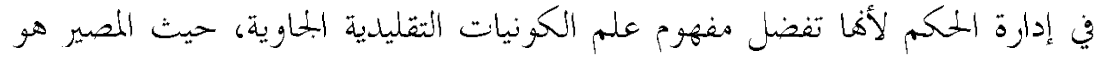

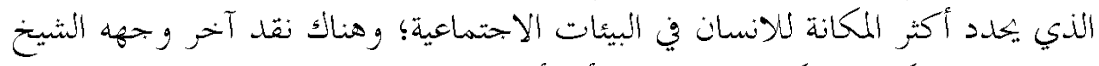

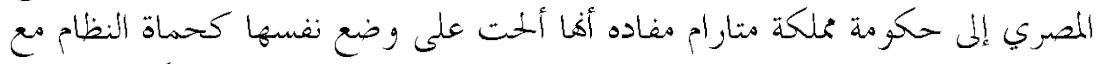

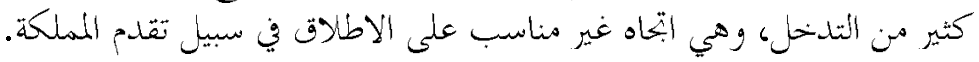

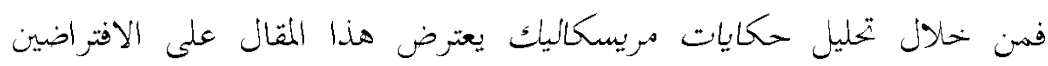

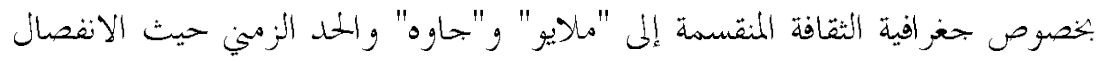

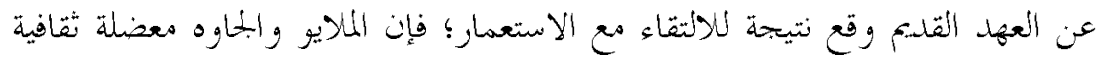

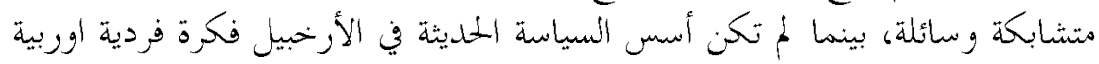

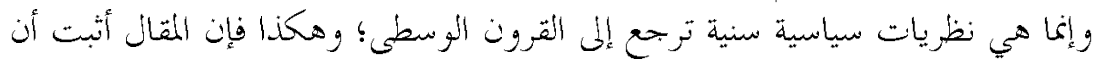

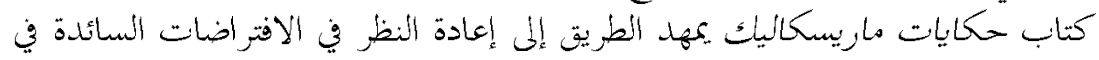
الدراسات عن جنوب شاب شاب ماتس آسيا. 
nn Stoler once wrote that literature and fictional work portray
sensibilities and sentiments that remain excluded from our
historical writing. Examining literature opens possibilities of examining what have been relegated to the descriptive fringes of scholarly histories of the colonial. ${ }^{1}$ While this essay shares Stoler's analytical approach of literature, it does not focus on the politics of affect. Rather, this essay examines an early nineteenth century literary production, the Hikayat Mareskalek, in an attempt to question various assumptions in contemporary works on the Malay-Indonesian archipelago. ${ }^{2}$ The first is the perceived geography of culture that is divided over what is considered 'Malay' and what 'Javanese.' The second is a temporal construct where a break with the past in the form of modernity occurred as a result of the shock of the colonial encounter. This attempt is framed in the study of authority and statecraft envisioned in the Hikayat. The first part of the essay tries to locate the spatial context of the Hikayat while the second reconstructs ideas of authority and statecraft enshrined in the text.

\section{Disrupting the Geography of Culture}

Before focusing on the vision of authority and statecraft that makes up the central theme of the Hikayat Mareskalek, it is important to specify the place this literary work occupies. In doing so, I will look at the author, the history of the production of the text as well as examine its contents while arguing that the text disrupts the notions of what is regarded as 'Malay' and 'Javanese' in the late-nineteenth century colonial project in the Dutch East Indies and British Malaya. Locating the Hikayat Mareskalek will help to understand its criticism of Javanese authority and statecraft in the subsequent section.

Shaykh 'Abdullāh b. Muhammad al-Miṣrī lived in the late eighteenth and early-nineteenth century. The dates of his birth and death are unknown, but from what can be gathered from his works, he lived during several important transitions in the Archipelago, such as the British (1811-1816) interregnums as well as the emergence of the Dutch East In dies. We know that he was born in Palembang of Egyptian origins and that his family lived in Kedah, in the Malayan Peninsula prior to settling in South Sumatra. From his works we can also deduce that he had lived in Pontianak and had established a cordial relationship with Sultan Syarif Kasim who ruled from 1808-1819. In the later part of his 
life, al-Mișrī lived as a merchant in Besuki, East Java. We also know that al-Misri accompanied the Hadrami Sayyid Hasan b. 'Umar al-Habshī, a merchant from Surabaya, on his visit to Siam in 1823 and to Bali in 1824. Both journeys were instructed by the Dutch Governor-General Van der Cappelen (in office 1819-1826) and al-Misri accompanied alHabshī in the capacity of an unpaid secretary. ${ }^{3}$

If al-Mișrî’s life story attests to his mobility, the writing of his text was a similar mobile endeavor. From the text, we know that the Hikayat Mareskalek was written five years after Marshal Daendels (in office 1808-1811) had departed and that it was written under terrible longing for Pontianak and its inhabitants, especially for Sultan Syarif Kasim and his family (92). He writes that one of the reasons he composed the Hikayat was that his longing for the Sultan, his family and the people of Pontianak had become unbearable. From here, it is safe to assume that the Hikayat was written during his years in Besuki, East Java, and it was dedicated to the Pontianak royal family. One of the two manuscripts, Cod. Or. 1724, that have survived to this day was copied by Encik Ismail who was the scribe to the Resident of Riau in Tanjung Pinang in 1827 (111), while the second, Cod. Or. 2276, was copied by Kiayi Rangga Satyanandita Ahmad bin Kiayi Ngabehi Mastung from Palembang in 1830. Both manuscripts from part of the collection of the Library of Leiden University.

Both al-Miṣrīs life story and the history of the text's production add to the difficulty in locating Hikayat Mareskalek in a fixed geographical space. The text begs to question the contemporary accepted paradigm in the study of Southeast Asia, which adopts the nation-state as the unit of study, thereby seeing the nation as describing the limits of cultures of modernity. An important underpinning in this perspective originates from Benedict Anderson whose views were built around the idea of colonialism as forming a radical break, which introduced modernity to a 'traditional' Southeast Asia. ${ }^{4}$ The geographic separations that were created between Javanese and Malay identities and discourses became the basic points of departure of analysis. In response to this tendency, Adrian Vickers argues that the isolation of 'Malay' from 'Javanese' "runs against the grain of indigenous discursive fields." That is to say, the colonial reconstitution of 'Malay' as a field of knowledge and identity cannot be separated from the reconstitution of 'Java.' Vickers suggests 
that the study of literary texts allows us to view more complex and ambiguous 'Malay' and 'Javanese' identities and discourses.

To understand this important point, it is helpful to look at two recent works that examine the construction of the essentialized notion of 'Javanese' and 'Malay. The first work is John Pemberton's study of constructions of 'Java.' Simply put, Pemberton argues that the constructed Javanese tradition that legitimates the New Order government is a hegemonic colonial construct. That is, 'Java' is a cultural form that subsumes or appropriates alternative cultural modes of action. ${ }^{6}$ As a cultural form, 'Java' was historically instituted and often became pronounced just when reality weakened. Thus for Pemberton, the project of spiritualizing the production and consumption of culture by detaching it from the social and the economic, reduces the symbolic life of society to a set of ritualizations. The second work is Henk Maier's study of the Hikayat Merong Mahawangsa, where he examines the role of colonial scholars-administrators such as Sir Richard Winstedt in codifying and constructing 'the Malay tradition'. According to Maier, Winstedt really believed that he knew the Malay and knew what was good for them more than the Malay themselves. ${ }^{7}$ Thus, Maier exposes the contestations between British scholars over the definition of Malay culture and over who could speak authoritatively over such matters. Both Pemberton and Maier challenged the essentialized cultural constructions of Java and Malay by exposing the political mechanisms behind them. By challenging culturalist assumptions, both Pemberton and Maier show that the so-called 'centers of authority' in Malay and Javanese literature and culture are not the literary areas of Riau-Lingga-Johor and Solo but the colonial processes by which scholars-administrators decided what was proper Javanese or Malay and what was peripheral.

Pemberton and Maier's contributions to the study of Javanese and Malay cultural constructs then should lead scholars to the next stage of study, that of examining cultural productions that did not fit the colonial paradigm. This also means observing cultural output that challenges the dichotomy of Malay and Javanese identities and discourses, which until today is still prevalent in state-centered projects that limit their focus on present-day national boundaries. Nancy Florida for instance, in her study of the Babad Jaka Tingkir inspects a non-canonical Javanese literary text, which was excluded from the colonial literary project. According to Florida, this Babad "interrupts the dominant ge- 
nealogical style of the dynastic chronicle to treat the past episodically, to generate a novel genealogy of the future" while bringing to light "a handful of peculiar characters on the margins of the dominant literary, historical, and cultural traditions" ${ }^{8}$ It is also important to note that the Babad Florida studied was written not in the "center of authority" but in the "margin" as it was composed in the Moluccas. Such an approach therefore, disrupts colonial cultural assumptions and exposes the categories of 'Javanese' and 'Malay' to further problematization.

The Hikayat Mareskalek offers a form of 'Malay' and 'Javanese' identities different from that of the separate and reified colonial construct. In the text, 'Malay' and 'Javanese' identities are defined as mutually constitutive with reference to literature, geography, and language, and while always interacting with the European presence it was at the same time formed in conjunction with other, non-European categories. Thus in the text, Marshal Daendels is not merely presented as a foreign Governor-General but also as a Javanese king who even took the title Tuan Susuhunan Kangjeng Kangsinuhun Mangkurat Mangkubuwana and gives away royal Javanese titles to his subordinates (106). He is portrayed as a ruler who criticizes the ruling Javanese families such as the Cirebon and the Solo royal houses by drawing from the corpus of Javanese dynastic history. Thus, when Daendels is criticized by one of the princes of Cirebon for bestowing royal titles to a commoner, the enraged Daendels tells two stories. The first conveys the story that the Javanese used to be infidels worshipping Dewa Mambang until a person from Palembang arrived in Java, converted its inhabitants to Islam, and subsequently became king. The second story regards Ki Ageng Pamanahan who was a wise farmer who foretold the demise of Arya Penangsang of Jipang. For that, he was given the land of Mataram by the Sultan of Pajang and from him descended the two present royal houses of central Java (100). The two stories that Daendels narrated, present a different picture of 'Java,' one that is fluid and shifting, in which anyone, whether from a different race (Daendels), region (Palembang), or class (farmer) could become ruler. There is no essence to Java in this story. What is demonstrated is precisely the impossibility of an autochthonous Javanese identity.

Another anecdote in the text is that of a Chinese merchant who requests the appanage over Banger, Besuki and Panarukan from Daendels (110). After having received them, he became known as the Mayor van 
Hir and was later recognized by the priyayi as the Raja Mangku Ningrat. One of his nephews converted to Islam and married the daughter of the prince of Sumenep and thus, 'the daughter of the ruler of Madura was brought in a procession, crossing to Java and merging the custom of the princess with that of the Chinese continent' (111). In this story, we see a Chinese who becomes Javanese through his appanage and title and another through converting to Islam and marrying into a Javanese noble house. Similar to the stories narrated by Daendels, this anecdote presents a situation of an absence of demarcated physical spaces of influence but rather, presents that of cultural overlaps.

Just as the text challenges the idea of a reified 'Java', it also tests the idea of standardized Malay. While written in Malay, the Hikayat Mareskalek is full of Arabic quotations from the Qur'àn, the Hadith, and poetry. Arabic words that are used throughout the text are simply left untranslated, such as al-haqìr (the debased one), gilmān wa ummāl (slaves and workers), musannif (author) and $q \bar{i} l$ (it is said). There are also untranslated Javanese words such as the titles of the nobles, informative words like merana-merena (to go here and there), cardinal directions like wetan, kulon, kidul and lor as well as verbs such as menembang (to sing a poem). European words can also be found in the text, such as in titles, in terms of address like menir (mister), in nouns like cepiau (hat), $j u$ (juice), kar (map). In addition, many of the conversations between Daendels, his colleagues and his subordinates are written in colloquial Betawi language inflected by Hokkien (such as in the usage of gua and $l u$ ). There are cases where words of different origins are present in one sentence such as when Daendels ordered one of his subordinate, "Kampungkan rakyat, gua mau berjalan ke tanah wetan" (Gather the people in the village, I want to make a journey to the East) (106). In this sentence, the word rakyat is a Malay word of Arabic origin, gua is Betawi from Hokkien, and wetan is Javanese.

The language of the text therefore projects a kind of Malay that existed without standardization in many different registers and yet was clearly understood and used for communication. To use Maier's term, Malay was 'a slippery continuum, that is, a continuous switching between codes and styles. ${ }^{\prime 9}$ Such heteroglossia worked to the satisfaction of a heterogeneous society because its styles allowed it to absorb contrary cultural currents. The 'switching between codes and styles' in a way acted as an avenue through which local identities met and assimilated 
external influences. In this regard, the roles of non-Malay diasporas such as the Peranakan Chinese, Hadhrami Arabs, and Eurasians were paramount in popularizing and hybridizing what came to be known as Malay. ${ }^{10}$ The language of the text, similar to the life of the author and the history of the text's production expressed an archipelagic region in which dichotomies of modern colonial and nationalist regimes have no place. Rather, it presents a space shaped by global migrations and cultures tied together by trade and internal movement. In this way, the medium of the text is in itself the message, conveying a culture in which there was little sense of 'inside' or 'outside' and where influences from outside were as much a part of it as anything local.

Up to this point, it has been made clear that the Hikayat Mareskalek offers a picture of 'Malay' and 'Javanese' as interconnected cultural complexes in motion. Such a notion challenges the dichotomy in the study of Southeast Asia that takes the nation-state as the basic unit of analysis. Standardized 'Malay' and 'Javanese' were intricately linked to colonial political strategies and subsequently appropriated by the nationalists to create national boundaries. The beginning of colonial modernity, which in the Hikayat is personified in the figure of Daendels, did not dislodge old cosmopolitanism but rather reinforced it. That is, with colonial modernity, old networks were re-energized and old channels of migration and cultural inter-penetration were revitalized. While al-Miṣrī himself was able to travel to Siam and Bali on colonial missions, in the Hikayat, Daendels criticized the Javanese princes for their insularity and rigidity. This criticism will be further explored in the next section.

Where then, should we situate al-Misri and his text for the purpose of analytical clarity? Using Denys Lombard's tripartite cultural systems that were at work in the archipelago-Western, Asiatic trade networks, and the traditional agrarian kingdom - we can locate al-Misri's in the second. ${ }^{11}$ The Asiatic trade network represented an open society that looked towards the ocean, where local and external influences were sedimented in the port-cities to produce a mobile, heterogeneous, dynamic, and fluid notion of culture different from the colonial and proto-nationalist constructions of both 'Javanese' and 'Malay' tied to particular geographical spaces. Establishing this position is very useful in helping us to trace how in useful ambiguous and shifting ways the author engages in a negotiation with the prevalent forms of authority, 
community, and statecraft in Java. It is to this question that we now turn.

\section{Statecraft, Authority, and the Economy}

This far we have been able to locate al-Misri within the context of the pasisir milieu. Understanding this crucial point gives us a better position to understand the criticism the text raises. In what follows, I will argue that the Hikayat is a didactic work, cleverly utilizing Daendels as a trope to describe the values and vices that a ruler should demonstrate and avoid. The Hikayat is not quite a work of history or a description of the world in which al-Misri lived. Despite the fact that descriptions of the contemporary context are present in the text, they are only used by the author to embark on his main project, that of criticizing the Mataram agrarian-based kingdom and its system of authority. While Daendels is indeed the focus of the text, its intended targets are the indigenous rulers of the archipelago, especially the two Mataram dynasties. Al-Misri clearly states in the beginning of the Hikayat that the story 'contains wisdom and cures to all kings and those who ruled over a territory' (92). In this section, I will attempt to examine several criticism al-Misri raises, reconstruct his political vision, and then compare it to medieval Sunni political theories to establish some resemblances. A caveat is in order: the exposition of Mataram statecraft below is far from being a comprehensive historical reconstruction. Rather, my discussion of Mataram statecraft, based on Soemarsaid Moertono's work, focuses on ideals rather than on actual historical experience, which may actually diverge from these ideals.

As a representative of the pasisir milieu, the basis of al-Misri's conceptualization of statecraft is trade. Quoting Yunan, the vizier of the Persian king Anusyirwan, al-Misri writes that a king should be stern and courageous, but most importantly, he should be able to attract trade to his realm by developing the resources under his dominion into trade commodities. If commerce prevails, al-Misri states, then no matter how cruel a king, traders will still come, 'like dogs which although been hit many times, would still return to the bones' (97). In his description of the VOC, he demonstrates that although the Company is very cruel, yet because it supports trade, traders continued to come and participate in the economy (97). Trade, according to al-Misri is the key to establishing welfare and prosperity in the realm, thereby placing the economy 
in the role of the key to a state's success. In the Hikayat, there is a story in which Daendels convenes sailors and traders in Semarang to listen to their grievances and their criticism of indigenous rulers (103-4). In this way, al-Misri hints on the concept of humans as economic beings who need trade and commerce to fulfill their needs. As commerce is imperative in the livelihood of people, the central raison d'être of statecraft is to ensure its smooth running.

Al-Misri's emphasis on commerce is in contradistinction to Mataram's version of statecraft. Soemarsaid Moertono, notes that the crucial underpinning of traditional Javanese cosmology was the dictum that fate determines man's place in society. ${ }^{12}$ In turn, social organization was seen as maintaining adherence to established social patterns where neither servants nor masters were allowed to transgress formal dividing lines. ${ }^{13}$ This form of organization was based on the agrarian economy of Mataram, where importance was placed on harmony and regularity located in the narrow space of the social village. Within this scheme, the king was seen as the protector of regularity rather than as developer. ${ }^{14}$ The Javanese court's view of order can be summed up as fixed regularity and non-interference from the state, thereby 'reflecting awareness of pattern in nature's behavior. ${ }^{15}$ By the time of al-Misri, this system of statecraft was no longer functioning properly. Sovereignty based on the lungguh (appanage) salary system continued to decrease as a result of the shrinking boundary of the kingdom in the face of the VOC's power. Such a system also became inadequate as the monetary economy gradually infiltrated Java. Here we see that al-Misri's emphasis on the interconnection between trade, the economy, and the state is a form of criticism against the agrarian Mataram system. In fact, one consequence of hierarchical Mataram society was the difficulties encountered in the formation of the individual, in contrast to al-Misri's vision of the economic individual as the basis of society. ${ }^{16}$

If flourishing trade is the objective of a kingdom, then the state's policy should reflect this aim. In the Hikayat, al-Misri criticizes the VOC for levying exorbitant taxes. He notes that if a merchant has a capital of 1000 riyal and his profit from trade is 500, while at the same time the Company levies 500 riyal tax, then in the end, the merchant would return to his initial capital without making any profit (94). Such a policy, according to al-Misri discourages trade from developing further. That is, although the Company is friendlier towards commerce, yet some of 
its policies obstruct further development in trade activities. Perhaps this criticism is also directed towards the Mataram rulers, whom according to Moertono put a heavy burden of taxes on the population. ${ }^{17}$

Another policy that is instrumental in the success of the state is the need for its government to establish information networks with its provinces. In describing the VOC, al-Misri writes that the central government in Batavia periodically checked the information from its branches, storing it in 'the Great Book' (94). Securing information in 'the Great Book' enabled the smooth transition from one ruler to another, as the next ruler could easily observe the state-of-affairs from the book (94). In al-Misri's words, 'it is not a tenuous effort to govern the country as all [information] is already contained in the text of the book...'(94), enabling effective connections between the central administration and the provinces. Such a centralized and inter-dependent form of government was quite different from the Mataram administrative style, which was characterized by highly autonomous, self sufficient administrative units, thereby keeping the organization of the state as simple as possible. ${ }^{18}$ This kind of administration was ideal for a policy of non-interference compatible with the agrarian lifestyle, 'whose narrow space does not need intensified communication with the outside world. ${ }^{19}$ However, for a polity based on commerce and extensive trade networks, as championed by al-Misri, Mataram's administrative style was insufficient. In addition, the highly autonomous administrative units in a state based on open trade networks would pose threats of disintegration.

If commerce-friendly policies are instrumental in the development of a flourishing economy, then functioning infrastructures are needed to ensure its implementation. Here, the Hikayat highlights Daendels' main legacy of building de Groote Postweg (the great mail road). AlMisri describes that among Daendels' orders is the construction of big road from West Java to the East while planting paddy and coffee beans to enable the production of trade commodities, which would result in greater commercial activities and attract more people to come to and stay in Java (97-98). Al-Misri argues that indigenous rulers do not know how to develop their natural wealth, requiring them to resort to taking money from the population (98). It is imperative to underline the importance of de Postweg both as a military and as a trading route. As a military route, de Postweg was built primarily to defend Java against 
the English who, at the time, ruled the seas in the Archipelago. ${ }^{20}$ As such, de Postweg functioned politically by linking the island's important settlements. In addition, it helped to secure the island from the threats of bandits and robbers, which was an established menace in Java. ${ }^{21}$

As a trading route, de Postweg brought trade to the interior and enabled transportation between towns. The construction of de Postweg altered the spatial configuration of Java. New markets and trading posts emerged in the interior securing the road as the main economic artery of the island. ${ }^{22}$ De Postweg assisted the commercialization of land resources in Java, establishing a unified economic zone on the island while helping to form a very important social group: intermediary traders. ${ }^{23}$ It has been reported that prior to the construction of the route, there was still no road in the most eastern parts of Java, and thus mobility in the area was seriously hampered. ${ }^{24}$ From here, we can see the reason for al-Misri's support for and praise of the road's construction. This infrastructure helped to realize the political and economic visions of alMisri. For instance, in the Hikayat, al-Misri narrates the story of several indigenous people who complain to Daendels about the hardship encountered in building the road. Daendels replies by quoting a Quranic verse, 'surely, with each difficulty there is ease (94:5)' (98). Thus, while noting the difficulties involved in the construction of de Postweg, alMisri stresses the importance of such a task to the welfare and prosperity of the island's inhabitants. Such a position is quite different for instance from the modern Indonesian writer Pramoedya Ananta Toer who stresses the oppression and exploitation through hard forced labor that Daendels used to complete the road while spending a low sum of money on the project. ${ }^{25}$ For al-Misri, therefore, de postweg is pivotal to the realization of his political and economic visions.

Another important point raised by al-Misri in the hikayat is that in running the state, a ruler must select able people to help him in governing. He tells a story of a person from the mountain, who is highly able in lending significant services to Daendels. As a result, Daendels bestows upon him a princely title (pangeran). One of the sons of the royal house of Cirebon, Pangeran Negara, approaches Daendels and protests the bestowing of royal title to a lowborn (100). The enraged Daendels then reminds the prince of the humble origins of Javanese kings while quoting a Quranic verse: 
O Allah...you give power to whom you please, and you strip power off whom you please: You endow with honour whom you please, and you abase whom you please $(3: 26)$.

In another place, al-Mișrī criticizes the concept of parity in marriage ( $k a f \bar{a}^{\prime} a b / k u f \bar{u}$ ) when telling the story of the marriage between the Chinese Baba Midun and the daughter of the prince of Sumenep (110). As Baba Midun is both a Muslim and an able individual, al-Misri argues that the marriage already fulfills parity. The central message of both stories is that position of authority should be given to those who truly deserve it and not just based on genealogy. This stands in contrast with the Mataram system, which stressed continuity of every ruling houses with their predecessors, to the extent that genealogical connections had to be invented. ${ }^{26}$ In addition, Lombard asserts that in the lower strata of the Javanese hierarchy, marriage functioned as a continuation of hierarchy with the aim to strengthen social cohesion. ${ }^{27}$ From here, al-Mișrì's more fluid hierarchy of rule seemingly attested to his pasisir background.

Envisioning the state, economy, and infrastructure of an ideal state is only part of al-Mișrīs message in the Hikayat. He also describes the traits that can be detrimental to a ruler. He does this in his description of Daendels as well as of the Javanese ruling elites. In discussing Java, al-Misri argues that people in Java are corrupted by mundane worldly activities without the guidance of pious ulama (96). He lists four causes for their weaknesses, namely, women, excessive food, extravagant clothing, and walking wira-wiri (96) — the last probably means wasting time walking around restlessly. In regards to the rulers, al-Miṣrī criticizes them for being busy with women night and day as well as amusing themselves with games like hunting and chess (99). The ministers are also weak and vain, only caring about titles (102). Al-Misri asserts that the indigenous rulers of Java are not in the habit of consulting with people of knowledge, which probably means the ulama (99). Here, alMisri points to the lack of justice among the rulers, whether justice to themselves or to their subjects. Justice in al-Mișrīss eyes is central to the running of the state and it seems that consultation with the ulama is vital to its realization.

Although applauded for his reasonable policy, Daendels is also portrayed as an arrogant and vain ruler; weak traits that finally lead to his downfall. A highly dramatic part of the Hikayat begins when Daendels assumes the title susubunan for himself (106). At night, he dreams of 
Sunan Kalijaga who appears with a heavy steel cane in his hand and admonishes Daendels for his arrogance and vanity in assuming the title. The frightened Daendels thinks that perhaps the cane in Kalijaga's hand was the same cane Moses used when he divided the Red Sea (106). The symbolism of the cane is telling as Moses was a prophet who was sent with a message of justice to an arrogant pharaoh. Following the dream, Daendels leaves to visit the sacred places of Java, first to the palace and shrine of Cirebon (Sunan Gunung Jati), then to the Demak mosque, and finally to the shrine of Giri in Gresik.

During his visit to the Demak mosque, Daendels orders a ship engineer to measure the qibla alignment and to his surprise, the engineer tells him that the measurement is very precise as if the builder actually saw the Ka'ba in front of him. Daendels becomes more frightened as he realizes Sunan Kalijaga's saintly power and authority (107). Nancy Florida discusses the construction of the Demak mosque and she demonstrates the establishment of a center that 'recognizes no single absolute temporal authority'. ${ }^{28}$ By reiterating this story, alMiṣrī seemingly emphasizes the authority of the saints, which should coexist with and not be subsumed under state authority. The repentant Daendels warns the ruling family of Solo that if they continue to use the title susubunan, which is originally meant for the saints, their kingdom will eventually perish (170).

To comprehend al-Mișrīs criticism here, we have to look at the constellation of authority in the Mataram kingship system. When the kingdom of Demak was established, Raden Patah, its first ruler, entered into an agreement with the saints to divide authority into the interrelated spheres of religion and the state. ${ }^{29}$ In this constellation, the king was answerable to the saints. The saints also acted as arbitrators between feuding ruling elites, such as in the conflict between Panembahan Senapati and Pangeran Surabaya, which was settled by the lords of Giri. $^{30}$

With the consolidation of the Mataram kingdom under the aegis of Sultan Agung, however, the old constellation was gradually dismantled, marked by the pacification of the four centers of religious authority. Giri was pacified by Sultan Agung but only successfully destroyed by Amangkurat II in 1680; Cirebon came peacefully under Mataram by treaty in 1590; Adilangu, the seat of Kalijaga's descendants waned gradually; and Kajoran, the seat of the descendants of Sunan Padang Aran, 
was annihilated in $1679 .{ }^{31}$ This process marked Mataram's attempt to recapture undivided sacro-political power mirroring the old Majapahit style, which became reflected in Sultan Agung's usage of the title sunan and in its inflated form of susubunan. ${ }^{32}$ The new constellation secured kingship as sacral and temporal power, subsuming the ulama as part of the king's administration in the form of Reh Pengulon. Having said this, it becomes clear that in al-Misri's vision, the ulama should be an independent entity to which monarchs should turn for consultation. Only by establishing communication between the monarch and the ulama on an equal footing, can the king ensure that he is within the limit of justice.

This far I have reconstructed the vision of authority, statecraft, and the economy in the Hikayat Mareskalek. In what follows I will try to show how al-Misri's visions demonstrates continuity with Sunnī political theories, especially those elaborated by al-Māwardī, Niẓām al-Mulk, and al-Ghazālī. The tenth century witnessed a realignment of the political constellation in the heartland of the Abbasid Empire, when the Saljuks assumed power. Under the Saljuks, a religio-political pattern emerged under which ulama administered Islamic justice. In this regard, Sunnism developed as a full partner of the military-political power where the Sultan and leading ulama cooperated and became inter-dependent. ${ }^{33}$ Within this context, the three aforementioned thinkers attempted to draw up the political ideals of an Islamic polity that reflected this changing constellation.

According to these thinkers, the authority of the ruler is based on military power and yet is limited by the law as interpreted by the ulama. The basic assumption for this arrangement is the individual as an economic animal, essentially in need of commerce and trade. This necessitated the authority of the state to facilitate trade and to meet the need for justice, which would assure the flourishing of commerce within the boundaries of ethics and the law. ${ }^{34}$ Al-Māwardī argues however, that justice can only be achieved when the individual enjoys economic wellbeing. ${ }^{35}$ Thus for him, it is imperative that private property should be respected and that taxation should only be levied in accordance with the law. ${ }^{36}$ Therefore, the picture that emerged here is that sovereign power is a divine, God-ordained good in order to maintain and to extend His law and hence the principal function of the government is to enable the individual to lead a good life within in confines of Islamic ethics. ${ }^{37} \mathrm{In}$ 
this respect, justice is attained when religious and worldly interests are perceived to converge, thereby affirming the ulama as an essential part of the social order. ${ }^{38}$

It is clear from this exposition that the basic assumption of Sunni political theory is the concept of the-individual-in-the-community, as an economic being bounded by ethics. The state should therefore also actively partake in the advancement of trade and civilization by constructing canals, roads, and other infrastructures. ${ }^{39}$ In addition, a ruler must be mindful of flattery and vanity, thus, for al-Ghazāli it is important for a ruler to establish information networks so that he can learn the true opinions of his subjects. ${ }^{40}$ Knowing the criticism of his subjects will aid a king to be a better ruler.

As justice is assumed to be based on divine standards and can only be achieved by following the law, then the position of the ulama should be independent of the executive authority of the monarch. In fact, alGhazāli argues that the second important trait a ruler must attain after justice is the habit of keeping the company of the ulama.$^{41}$ He writes,

'O Sultan, justice springs from perfection of the intellect and that means that you see things as they really are and perceive the facts of their inner reality without being deceived by their outward appearance. ${ }^{42}$

This quotation is striking, as al-Ghazālī seemingly attempts to infuse the Sufi understanding of ma'rifa (gnosis, for lack of a better term) into politics. In fact, most anecdotal examples al-Ghazālī gives to illustrate the importance for a ruler to keep the company of the ulama are derived from the story of the king's relationship with Sufi saints such as Shaqiq al-Balkhī and Fuḍayl b. 'Iyaḍ. ${ }^{43}$ This indicates that although al-Ghazālī shares the opinion of al-Māwardī and Nizām on the importance of the ulama to statecraft, his discussion is more precise in that what he means by ulama were actually not only jurists, but also Sufi saints who have reached ma'rifa.

This brief discussion on Sunni political theory highlights many similarities with al-Misri's political visions. More precisely, in the Hikayat, Daendels even quotes the circle of power expounded by alMāwardī, Nizāam, and al-Ghazālī (102-3). ${ }^{44}$ This Circle of Power encapsulates the political vision described above: There can be no royal authority without subjects-there can be no subject without wealth - there can be no wealth without infrastructure-there can be 
no infrastructure without justice — there can be no justice without royal authority.

\section{In Lieu of a Conclusion}

The preceding discussion demonstrates that al-Misri's political vision is not based on modern European concepts that came about as a result of encounters with European colonizers. Rather, it indicates a continuity with medieval Sunni political theories. Al-Misri's vision shows a clear concept of the individual as an economic being who acts as the basic political unit which also functions as the raison d'être for the establishment of a polity. This discussion is thus in contradistinction to the work of Anthony Milner who argues that the Kerajaan in the Malay World was 'pre-political.' That is, it should not be regarded as a secular but as a religious sphere and system where a strong sense of individual consciousness was not present. ${ }^{45}$ Milner claims that Munsyi Abdullah was the earliest indigenous author to draw from Western-derived concepts to undermine the Kerajaan. Experimenting with new liberal and protestant ideas, Abdullah's writings emphasize the new notions of the individual, of historical development, of social organization and geographical knowledge, which challenged the entire discursive foundation of the Kerajaan. ${ }^{46}$ For Milner the very assumption of a public of individuals was the most fundamental of this new politics, which emerged as an impact of colonialism that provided the context for this discursive transformation. ${ }^{47}$ Thus, the central logic of Milner's argument amounts to historicism, emphasizing the idea of development first in Europe and only then in other places to constitute a global narrative of history. ${ }^{48}$

By analyzing the Hikayat Mareskalek, this essay argues against both the perceived geography of culture that divided what is considered 'Malay' and 'Javanese; as well as the supposed temporal threshold where a break with the past occurred as a result of the shock of the colonial encounter. Rather, the Hikayat demonstrates 'Malay' and 'Javanese' as interconnected and fluid cultural complexes in motion. Such a notion challenges the dichotomy in the study of Southeast Asia that takes nation-states as its basic units of analysis. For reason of analytic clarity, perhaps, the Hikayat can be located in the context of the pasisir system based on the littoral, which is itself a place characterized by 'ambiguity, lack of definition and boundaries, a zone where land and seas intertwine and merge...' ${ }^{49}$ 
Another important point highlighted by the Hikayat is that the concept of the individual as the basis of modern politics that has been seen to enter the Archipelago with the colonial encounter should be rethought. While the colonial encounter is featured in the Hikayat, the message is not dialogical but monological. That is, only the voice and values of the self exist in the story and that the other can only be understood within the framework of the self's culture. ${ }^{50}$ Thus Daendels is portrayed here as a messenger of medieval Sunni rather than modern European political thought. This calls into question the prevalent periodization, which locates the Europeans as the only precursor of the modern era in the Malay-Indonesian Archipelago. What is reflected, rather, is a long-standing antagonism between the agrarian world and the trading system, which according to Denys Lombard constitutes one of the keys in understanding the history of the archipelago. ${ }^{51}$

Hikayat Mareskalek thus provides an avenue where various assumptions of Southeast Asian studies can be revisited. Not only that it de-centers the assumption of a fixed geography of cultures, but also the historical meta-narrative. As a text filled with ambiguities, it also portrays the relationship between the colonizers and the colonized in an ambivalent manner. Thus, Daendels is praised for his policy but at the same time he is criticized for his vanity and arrogance. He subdues the Javanese princes but is also finally subdued by a deceased saint. This reminds us of Homi Bhabha's conception of ambivalence in the colonial relation, where the colonized fluctuates between complicity and resistance, which disturbs the relationship between the colonized and the colonizers. ${ }^{52}$ Thus the Hikayat Mareskalek offers a number of avenues to revisit and question contemporary categories in Southeast Asian studies as well as rethinking its historical logics and assumptions. 


\section{Endnotes}

1. Ann Laura Stoler, Carnal Knowledge and Imperial Power: Race and the Intimate in Colonial Rule (Berkeley: University of California Press, 2002) p. 12.

2. Monique Zaini-Lajoubert, Abdullah bin Muhammad al-Misri (Bandung: Penerbit Angkasa \& Ecole française d'Extrême-Orient, 1987). This work has ben republished with some revisions by the Publisher Komunitas Bambu and EFEO in 2008 For the sake of convenience, the page numbers of quotations from the hikayat are incorporated in the body of the essay.

3. Information on al-Misri's life is taken from the preface to the Karya Lengkap written by Monique Zaini-Lajoubert. See: Zaini-Lajoubert, Abdullah bin Muhammad al-Misri, p. 14.

4. See for instance, Benedict Anderson, "A Time of Darkness, A Time of Light: Transpostition in Early Indonesian Nationalist Thought," in Language and Power (Ithaca: Cornell University Press, 1990) pp. 241-270.

5. Adrian Vickers, “'Malay Identity': Modernity, Invented Tradition and Forms of Knowledge," in Contesting Malayness: Malay Identity across Boundaries, edited by Timothy P. Barnard (Singapore: Singapore University Press, 2004) p. 26.

6. John Pemberton, On the Subject of 'Java' (Ithaca: Cornell University Press, 1994).

7. Hendrik M.J. Maier, In the Center of Authority : the Malay Hikayat Merong Mahawangsa (Ithaca: Cornell Southeast Asia Program, 1988) p. 59.

8. Nancy Florida, Writing the Past, Inscribing the Future: History as Prophecy in Colonial Java (Durham: Duke University Press, 1995) p. 9.

9. Hendrik M.J. Maier, "From Heteroglossia to Plyglossia: The Creation of Malay and Dutch in the Indies," Indonesia, 56 (1993) p. 47.

10. T.N. Harper, "Empire, Diaspora and the Languages of Globalism, 18501914," in Globalization in World History, edited by A.G. Hopkins (London: Pimlico, 2002) p. 153.

11. Denys Lombard, Nusa Jawa: Silang Budaya (Jakarta: Gramedia 1996) vol. III, pp. 169-170.

12. Soemarsaid Moertono, State and Statecraft in Old Java: A Study of the Later Mataram Period, $16^{\text {th }}$ to $19^{\text {th }}$ Century (Ithaca: Cornell Modern Indonesia Project Monograph Series, 1963) p. 26.

13. Ibid, p. 15.

14. Ibid, p. 4.

15. Ibid, p. 37.

16. Lombard, Nusa Jawa, III, p. 58.

17. Moertono, State and Statecraft, p. 47.

18. Ibid, p. 88.

19. Ibid, p. 92.

20. Peter J.M. Nas \& Pratiwo, "Java and De Groote Postweg, La Grande Route, the Great Mail Road, Jalan Raya Pos," Bijdragen tot de Taal-, Land-en Volkenkunde, 158, 4 (2002), p. 709. 
21. Moertono, State and Statecraft, p. 85.

22. Nas \& Pratiwo, "Java and De Groote Postweg," p. 719.

23. Lombard, Nusa Jawa, I, pp. 74 \& 139.

24. Ibid, I, p. 139.

25. Pramoedya Ananta Toer, Jalan Raya Pos, Jalan Daendels (Jakarta: Lentera Dipantara, 2005).

26. Moertono, State and Statecraft, p. 53.

27. Lombard, Nusa Jawa, III, p. 75.

28. Nancy Florida, Writing the Past, Inscribing the Future: History as Prophecy in Colonial Java (Durham: Duke University Press, 1995) p. 336.

29. Moertono, State and Statecraft, p. 30.

30. Ibid, p. 113.

31. Ibid, pp. 31-33.

32. Ibid, p. 33.

33. Antony Black, The History of Islamic Political Thought: From the Prophet to the Present (New York: Routledge, 2001) p. 81.

34. Abū Hāmid al-Ghazālī, Ihyyà' 'Ulūm al-Dīn (Cairo: Dār al-Salām, 2003) vol. II, book. 26, pp. 1120-1123.

35. 'Alī b. Muhammad al-Māwardī, Adab al-Dunyā wa al-Dīn (Cairo: Mușțafā al-Bāb al-Hilabī, 1955) pp. 192-3.

36. 'Alī b. Muhammad al-Māwardī, al-Aḅkām al-Sulțāniyya wa al-Wilāyāt alDiniyya (Cairo: Muṣțafā al-Bāb al-Hilabī, 1966) pp. 146-152.

37. Bernard Lewis, The Political Language of Islam (Chicago: The University of Chicago Press, 1988) p. 29.

38. Nizām al-Mulk, The Book of Government or Rules for Kings, translated from the Persian by Hubert Darke (London: Routledge \& Kegan Paul, 1960) pp. 43-47.

39. Ibid, p. 10.

40. Abū Hāmid al-Ghazālī, Book of Counsel for Kings, translated from the Persian by F.R.C. Bagley (London: Oxford University Press, 1964) p. 30.

41. Ibid, p. 19.

42. Ibid, p. 24.

43. Ibid, pp. 19-22.

44. It should also be noted that in the kingdom of Palembang, where al-Misri grew up, the sunni political constellation was implemented before colonial expansion. While the sultan was the executive head, the Pangeran Penghulu Nata Agama had absolute authority over religious and ethical issues. See: Husni Rahim, Sistem Otoritas \& Administrasi Islam (Jakarta: Logos, 1998) p. 257.

45. Anthony Milner, The Invention of Politics in Colonial Malaya (Cambridge: Cambridge University Press, 1995) p.26.

46. Ibid, p. 84.

47. Ibid, pp. 291-2. 
48. For a thorough elaboration and critique of this concept see: Dipesh Chakrabarty, Provincializing Europe: Postcolonial Thought and Historical Difference (Princeton: Princeton University Press, 2000).

49. Michael Pearson, The Indian Ocean (London: Routledge, 2003) p. 37.

50. The concept of monologue as oppose to dialogue is proposed by Tzvetan Todorov in his study of the Spanish conquest of America. See: Ben Murtagh, "Introduction," in The Portrayal of Foreigners in Indonesian and Malay Literatures, edited by Vladimir Braginsky \& Ben Murtagh (Lewiston: Edwin Mellen, 2007) p. 7.

51. Lombard, Nusa Jawa, vol. III, p. 175.

52. Homi K. Bhabha, The Location of Culture (London: Routledge Classics, 2004) pp. 121-31.

\section{Bibliography}

Anderson, Benedict. "A Time of Darkness, A Time of Light: Transpostition in Early Indonesian Nationalist Thought," In Language and Power. Ithaca: Cornell University Press, 1990.

Bhabha, Homi K. The Location of Culture. London: Routledge Classics, 2004.

Black, Antony. The History of Islamic Political Thought: From the Prophet to the Present. New York: Routledge, 2001.

Al-Ghazālī, Abū Hāmid. Iḥyā' 'Ulūm al-Dīn. Cairo: Dār al-Salām, 2003.

Al-Ghazālī, Abū Hāmid. Book of Counsel for Kings, translated from the Persian by F.R.C. Bagley. London: Oxford University Press, 1964.

Harper, T.N. "Empire, Diaspora and the Languages of Globalism, 1850-1914," in Globalization in World History, edited by A.G. Hopkins. London: Pimlico, 2002.

Lewis, Bernard. The Political Language of Islam. Chicago: The University of Chicago Press, 1988.

Lombard, Denys. Nusa Jawa: Silang Budaya. Jakarta: Gramedia 1996.

Maier, Hendrik M.J. In the center of authority. Ithaca, NY: Cornell University Press (1988)

Maier, Hendrik M.J. "From Heteroglossia to Plyglossia: The Creation of Malay and Dutch in the Indies," Indonesia, 56 (1993).

Al-Māwardī, 'Alī b. Muhammad. Adab al-Dunyā wa al-Dīn. Cairo: Muṣṭaāa alBāb al-Hilabī, 1955.

Al-Māwardī, 'Alī b. Muhammad. al-Aḥkām al-Sulțānìya wa al-Wilāyāt al-Dīnīya. Cairo: Muṣțafā al-Bāb al-Hilabī, 1966.

Milner, Anthony. The Invention of Politics in Colonial Malaya. Cambridge: Cambridge University Press, 1995.

Moertono, Soemarsaid. State and Statecraft in Old Java: A Study of the Later Mataram Period, 16th to 19th Century. Ithaca: Cornell Modern Indonesia Project Monograph Series, 1963. 
Murtagh, Ben. "Introduction," in The Portrayal of Foreigners in Indonesian and Malay Literatures, edited by Vladimir Braginsky \& Ben Murtagh. Lewiston: Edwin Mellen, 2007.

Nas, Peter J.M. \& Pratiwo, "Java and De Groote Postweg, La Grande Route, the Great Mail Road, Jalan Raya Pos," Bijdragen tot de Taal-, Land-en Volkenkunde, 158, 4 (2002).

Nizām al-Mulk. The Book of Government or Rules for Kings, translated from the Persian by Hubert Darke. London: Routledge \& Kegan Paul, 1960.

Pearson, Michael. The Indian Ocean. London: Routledge, 2003.

Rahim, Husni. Sistem Otoritas \& Administrasi Islam. Jakarta: Logos, 1998.

Stoler, Ann Laura. Carnal Knowledge and Imperial Power: Race and the Intimate in Colonial Rule. Berkeley: University of California Press, 2002.

Toer, Pramoedya Ananta. Jalan Raya Pos, Jalan Daendels. Jakarta: Lentera Dipantara, 2005.

Vickers, Adrian. "'Malay Identity': Modernity, Invented Tradition and Forms of Knowledge." In Contesting Malayness: Malay Identity across Boundaries, edited by Timothy P. Barnard. Singapore: Singapore University Press, 2004.

Zaini-Lajoubert, Monique. Abdullah bin Muhammad al-Misri. Bandung: Penerbit Angkasa \& École française d'Extrême-Orient, 1987.

Ismail F. Alatas, Ph.D student at Michigan University, USA 